\title{
Editorial
}

\section{Alignment, attunement, co-activity, co-regulation: convergent trajectories?}

The latest years educational research has focussed on the action seen as space-time in which learning and teaching interact.

Already in the constructivist approach the interaction, anyway, played a central role, also due to the influence that Vygotskji had in the second half of the last century.

But the direction was objectively different, since the attention was on how the interaction affected learning and how the relationship with the expert could make the learner, then, access his/her own Zone of Proximal Development.

Till the most recent researches that have highlighted the no-linearity between teaching and learning by also exploring the role played by noncognitive aspects, and by underlining how the influence is not direct, but mediated.

The mediation was meant in two ways.

In the first, mainly of constructivist matrix, the teacher would foster the learning processes by setting a number of dispositifs/environments. The learner would rethink and restructure the previously acquired concepts in those dispositifs/environments or in the relation with them. Thus in such approach the role of the teachers would be indirect and would passes through the environment.

The second meaning of mediation, instead, puts at the centre the process in which teaching and learning interact (the didactical action) and the concepts are restructured with recursive paths in which the related viewpoints (the teacher's one and the students' one) change in an enactive way. The space of action can, thus, become, space of transformation and self-regulation of the two actors.

What would happen if, as said, the relation wasn't linear? That is if, from teaching, even if effective, didn't affect mechanically learning?

The Merleau-Ponty ambiguity concept would come into play, that is, the chance of having an accord between the two actors, even if the difference between them persists.

This alignment process was highlighted by many authors in the last years even if the different proposals are not identical.

Here follows some of them. 
Laurillard (2012) speaks about alignment (ivi, 95, 100) and states in several significant contributions in the contemporary psycho-pedagogical literature, that it's a basic principle for teaching. She offers a series of proposals to promote it (99-108).

Lutzker, instead, focussed on attunement in different articles and also organized an EERA 2014 symposium on "Attunement and Education".

Vinatier and Numa-Bocage (2007) speak about co-activité and highlight how the accord during the interaction makes it possible to activate learning advancements.

The same topic is connected to wider researches activated in the last years, also outside the educational field. Berthoz speaks about empathy (2011), Gallese speaks about the relation between Embodied Simulation and Empathy and between "Embodied Simulation and Intentional Attunement" (2009) and underlines the relation between knowledge and action, and the role of mirror neurons. In other words the research on alignment would intertwine with the one on neurodidactics as it's testified by the wide researches by Laurillard (2014) and Rivoltella (2015), clearly besides the one by Gallese.

The previous proposals seem to have a common aspect on the central role of the action in the teaching/learning process.

The current issue wishes to investigate the topics of alignment, attunement, co-activitie, co-regolation: it aims at deepening the meanings of such concepts and the affinities among them and, clearly, to catch the directions for the didactical activity.

The articles face the different aspects of the multifaceted mentioned issues.

The contribution "La sindrome dello specchio. Apprendimento $e$ insegnamento nella prospettiva dell'Enattivismo" by Damiano opens the issue. It alerts the reader about the possible risks; the author mainly highlights what problems he believes the enactivist perspective is not able to solve.

The second article "Alignment" by Rossi, analyses the theme from different historical perspectives and tries, then, to catch the new meaning that the word acquires in the current context and the practices that result from it.

The article by Sibilio and Zollo, "The non-linear potential of didactic action" finds in the no-linearity and in the proposal of simplexity the possible answers to the current complexity.

Bonometti with "Start a community of practice through Action Learning:

nurse manager to support the changing care practices" gives a further perspective starting from a case-study analysis and the Action Learning approach.

Ambretti, Borgogni, Vastola, Di Gennaro, Medved and D'Elia in their article "The projects integrated school area for the promotion of motor activity: possible alignment professionals roles" address the problem of alignment among different professional roles. 
A similar perspective can be found in "Motor technique and didactics: a possible alliance from an educational point of view" by Palumbo, Franco, and Cereda.

The last contributions, finally, analyse alignment from a different angle: the one of inclusion.

In such a direction we have, thus, the articles by Caldin "I processi inclusivi nella prima infanzia tra diritti e responsabilità", by Charette "School-family-community collaborations: the contribution of the intercultural worker in accompanying newly immigrant parents to school" and the one by Dionne, Joly, Paquet, Rousseau and Rivard "Organizations' choices when implementing an Early Intensive Behavioral Intervention program (EIBI)".

Michele Corsi, Pier Giuseppe Rossi, Vladimir Megdeved 


\section{Editoriale}

Allineamento, sintonia, co-attività, co-regolazione: traiettorie convergenti?

La ricerca educativa, ultimamente, ha focalizzato la propria attenzione sull'azione vista come lo spazio-tempo in cui apprendimento e insegnamento interagiscono.

Già in ambito costruttivista l'interazione rivestiva comunque un ruolo centrale, anche per l'influsso che il pensiero di Vygotskji ha avuto nella seconda metà del secolo scorso

Ma la direzione di marcia era oggettivamente diversa, in quanto l'attenzione era concentrata su come l'interazione agiva sull'apprendimento e su come il rapporto con l'esperto permettesse, poi, al soggetto di accedere alla propria zona di sviluppo prossimale.

Sino a giungere alle ricerche più recenti, che hanno messo in evidenza la non linearità esistente fra insegnamento e apprendimento, esplorando anche gli elementi non cognitivi che intervengono e sottolineando come l'influenza fra insegnamento e apprendimento sia non diretta, ma mediata.

Con la mediazione che è stata intesa in due modi.

Nel primo, soprattutto di stampo costruttivista, il docente favorirebbe $i$ processi di apprendimento, predisponendo una serie di dispositivi/ambienti. In essi, o rapportandosi a essi, lo studente ripenserebbe e ristrutturerebbe i concetti pregressi. Sicché, in tale approccio, il ruolo del docente sarebbe indiretto e filtrato dall'ambiente.

La seconda accezione di mediazione mette, invece, al centro il processo durante il quale insegnamento e apprendimento interagiscono (l'azione didattica) e i concetti si ristrutturano con percorsi ricorsivi in cui i relativi punti di vista (quello del docente e quello degli studenti) si modificano in modo enattivo. Lo spazio dell'azione può così divenire spazio di trasformazione e auto-regolazione dei due soggetti.

Cosa accadrebbe, per contro, se, come si è scritto, il percorso non fosse lineare ovvero se dall'insegnamento, per quanto efficace, non discendesse meccanicamente l'apprendimento?

Entrerebbe qui in ballo l'ambiguità merleau-pontyana, ovvero la possibilità che si crei una sintonia fra $i$ due soggetti, pur permanendo la differenza tra gli stessi.

Molti sono gli Autori che negli ultimi anni hanno parlato di allineamento, anche se le loro proposte non sono identiche. 
Ne riportiamo alcune.

Laurillard (2012) parla di allineamento (alignment) (ivi, 95, 100) e sostiene, in base a molti e significativi contributi della letteratura psico-pedagogica contemporanea, che esso sia un principio basilare per l'insegnamento, avanzando, peraltro, una serie di proposte per promuoverlo (99-108).

Lutzker ha messo invece a fuoco il tema dell'attunement in vari suoi articoli e sul tema "Attunement and Education" ha organizzato pure un simposio a EERA 2014.

Vinatier e Numa-Bocage (2007) ragionano, per contro, di co-activité e mettono in evidenza come il raggiungimento di una sintonia durante l'interazione permetta l'innesco dei progressi di apprendimento.

Il tema si lega comunque a ricerche più ampie anche avviate negli ultimi tempi, e pure al di fuori dell'ambito didattico. Berthoz parla di empatia (2011), mentre Gallese scrive della relazione tra "Embodied Simulation and Empathy" e fra "Embodied Simulation and Intentional Attunement" (2009) sottolineando la relazione fra conoscenza e azione, e il ruolo dei neuroni specchio.

In altri termini, la ricerca sull'allineamento s'intreccerebbe con quella sulla neuro-didattica come le ricerche di Laurillard (2014) e Rivoltella (2015) testimoniano ampiamente, oltre a quelle di Gallese.

Con le proposte precedenti che sembrano avere un punto in comune sul ruolo centrale dell'azione nei processi di apprendimento e insegnamento.

Il presente fascicolo vuole quindi indagare $i$ temi dell'alignment, dell'attunement, della co-activitié e della co-regolazione; approfondire $i$ significati di tali concetti e le affinità fra gli stessi e, chiaramente, cogliere quali indicazioni ne emergano per l'agire didattico.

Con gli articoli che esaminano i vari aspetti del tema, di per sé polisemico.

Apre il numero il contributo di Damiano "La sindrome dello specchio. Apprendimento e insegnamento nella prospettiva dell'Enattivismo" che mette in guardia da possibili rischi e soprattutto evidenzia quali problemi, a suo parere, la prospettiva dell'enattivismo non riesce a risolvere.

Il secondo contributo, "Alignment" di Rossi, analizza il tema riprendendo diverse prospettive storiche e cerca, poi, di cogliere il significato nuovo che il termine assume nel contesto attuale e le pratiche che da essa derivano.

Il contributo di Sibilio e Zollo, "Il potenziale non lineare dell'azione didattica" trova nella non linearità e nella proposta della semplessità le possibili risposte alla complessità attuale.

Bonometti con "Avviare una comunità di pratica attraverso l'Action Learning: $i$ coordinatori infermieristici come supporto al cambiamento delle pratiche di cura" fornisce un'ulteriore prospettiva a partire dall'analisi di uno studio di caso e dalle prospettive dell'Action Learning. 
Ambretti, Borgogni, Vastola, Di Gennaro, Medved e D'Elia nel loro contributo dal titolo "The projects integrated school area for the promotion of motor activity: possible alignment professionals roles" affrontano il problema dell'allineamento fra differenti ruoli professionali.

In una prospettiva simile va il testo di Palumbo, Franco, Cereda "Motor technique and didactics: a possible alliance from an educational point of view".

Gli ultimi contributi, infine, analizzano l'allineamento da un'ulteriore visuale: quella dell'inclusione.

Si muovono pertanto in questa direzione gli articoli di Caldin "I processi inclusivi nella prima infanzia tra diritti e responsabilità", di Charette "Schoolfamily-community collaborations: the contribution of the intercultural worker in accompanying newly immigrant parents to school" e di Dionne, Joly, Paquet, Rousseau e Rivard "Organizations' choices when implementing an Early Intensive Behavioral Intervention program (EIBI)".

Michele Corsi, Pier Giuseppe Rossi, Vladimir Megdeved 